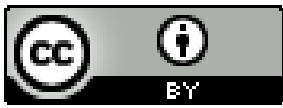

\title{
A LEI DOS SEXAGENÁRIOS COMO ESTRATÉGIA PARA MANUTENÇÃO DA PRECARIEDADE SOCIOESPACIAL NO
}

\author{
BRASIL
}

Julio Cesar Costa Manoel ${ }^{l}$

Resumo: Este artigo busca ampliar o debate entre o espaço, o tempo e o social, analisando a lei dos sexagenários de 1885 , entendida aqui como a última grande tentativa de manter a escravidão legal dos negros no brasil. O contexto marcado pela colonialidade, pelo gradualismo e pelo próprio diploma legal, reproduziram condições de precariedade para a população negra. A transição paulatina proposta pela elite se materializou como um retrocesso, e os debates para uma nova regra que trouxesse resultados significativos levantou questões socioespaciais, econômicas e políticas que proporcionaram um cenário favorável para a abolição definitiva da escravidão.

Palavras chaves: Escravidão; Liberdade; Gradualismo; Lei dos Sexagenários e Colonialidade.

\section{THE SEXAGENARIAN LAW AS A STRATEGY FOR MAINTAINING SOCIO- SPATIAL PRECARIOUSNESS IN BRAZIL}

\begin{abstract}
This article aims to broaden the debate between space, time and social aspects, analyzing the sexagenarian law of 1885 understood here as the last great attempt to maintain legal the slavery of blacks in brazil. The context marked by coloniality, gradualism and the legal diplomacy itself, reproduced precarious conditions for the black population. The gradual transition proposed by the elite was materialized as a regression and the debates for a new rule that would bring significant results raised socio-spatial, economic and political issues that provided a favorable scenario for the definitive abolition of slavery.
\end{abstract}

Key words: Slavery, Freedom, Gradualism, Sexagenarian Law and Coloniality.

\section{LA LOI SEXAGÉNAIRE COMME STRATÉGIE POUR MAINTENIR LA PRÉCARITÉ SOCIO-SPATIAUX AU BRÉSIL}

\footnotetext{
${ }^{1}$ Geógrafo pela Universidade Estadual do Rio de Janeiro (UERJ); Bacharel em Direito e Advogado pela Universidade Federal do Rio de Janeiro (UFRJ); Mestre em Direito pela Universidade Federal do Rio de Janeiro (UFRJ); Professor regente do ensino fundamental e médio na rede estadual do Rio de Janeiro. Email: juliogeouerj@yahoo.com.br
}

Revista da ABPN • v. 12, n. Ed. Especial - Caderno Temático: "Geografias Negras" • abril de 2020, p. 12-31 
Résumé: Cet article cherche a elargir le debat entre l'espace, le temps et le social, en analysant la loi sexagenaire de 1885, comprise dans cet article comme la derniere grande tentative de maintenir legal l'esclavage de noirs au bresil. Le contexte marque par le colonialite, le gradualisme et le diplome juridique lui-meme ont generes des conditions precaires a la population noire. La transition progressive proposee par l'elite s'est concretisee par un revers, et les debats sur une nouvelle regle qui apporterait des resultats significatifs ont souleve des problemes socio-spatiaux, economiques et politiques qui ont declenche un scenario favorable a l'abolition definitive de l'esclavage.

Mots clés: Esclavage, Liberte, Lradualisme, Loi Sexagenaire et Colonialite.

\section{LA LEY SEXAGENARIANA COMO ESTRATEGIA PARA MANTENER LA PRECARIEDAD SOCIOESPACIAL EN BRASIL}

Resumen: Este artículo busca ampliar el debate entre el espacio, el tiempo y lo social, analizando la ley sexagenariana de 1885 , entendida aquí como el último gran intento de mantener la esclavitud legal de los negros en brasil. El contexto marcado por la colonialidad, el gradualismo y el propio diploma legal, reprodujeron condiciones precarias para la población negra. La transición gradual propuesta por la élite se materializó como un revés, y los debates sobre una nueva regla que traería resultados significativos plantearon problemas socioespaciales, económicos y políticos que proporcionaron un escenario favorable para la abolición definitiva de la esclavitud.

Palabras clave: Esclavitud, Libertad, Gradualismo, Ley Sexagenaria y Colonialidad.

\section{INTRODUÇÃO}

Edward Soja (1993) nos propõe uma metodologia de pesquisa baseada no que chamou de entrelaçamento criativo. Este seria a união do materialismo histórico com o geográfico gerando uma dialética tríplice entre o espaço, o tempo e o social.

Nesse sentido, o processo de formação socioespacial do Brasil, como um país livre, atendeu a parâmetros específicos no tempo. As regras de convivência estabelecidas no pós-independência propiciaram uma construção de um cenário único que, ao ser estudado, nos revela transformações no espaço e no social.

Pensando na dialética tríplice proposta por Soja (1993), na dinâmica socioespacial da população negra do Brasil e na forma de atuação do Estado como determinante para a miserabilidade que este mesmo grupo foi exposto ao longo de nossa história, buscaremos nesse estudo nos debruçar sobre o fim do período imperial marcado pela tentativa de manter os negros presos ao cativeiro e limitar sua circulação pelo país.

Revista da ABPN • v. 12, n. Ed. Especial - Caderno Temático: "Geografias Negras"• abril de 2020, p. 12-31 
Estudaremos a última grande tentativa de manter a escravidão legal no Brasil efetivada através da Lei $\mathrm{n}^{\circ} 3270$ de 28 de setembro de 1885, também chamada de Lei dos Sexagenários. Este diploma legal se insere em um contexto marcado pela esperança e desesperança para o negro no Brasil, um período caracterizado por profundas transformações sociais e econômicas que favoreciam a liberdade dos cativos, porém politicamente impregnado pelo gradualismo, que tinha a real intenção de perpetuar o cativeiro pelo maior tempo possível no país (REIS, 2010).

Focados nesse recorte buscaremos como objetivo geral a análise do elemento espacial e social no processo de construção da Lei dos Sexagenários. Partindo desse contexto, indagamos quais os interesses presentes nos discursos gradualistas e na própria Lei de 1885 que proporcionaram a manutenção da precariedade socioespacial para os negros no Brasil.

Este estudo se justifica pela necessidade de ampliar o debate socioespacial nas pesquisas históricas, por apresentar considerações sobre as motivações das leis abolicionistas, em especial da Lei dos Sexagenários, contribuindo para o debate sobre a escravidão e precariedade da liberdade do negro no Brasil Império.

Para atender esse objetivo seguiremos como princípio metodológico o entrelaçamento de fontes primárias, como as atas legislativas e os textos das leis do Império (Anais da Câmara dos deputados do Império e Coleção de Leis do Império do Brasil.), com autores que escreveram suas obras no século XIX como José de Alencar (CARVALHO, 2009), Patrocínio e Rebouças (1883) e Malheiro (1886), seguido de obras contemporâneas como Saba (2008), Campello (2018) e Schwarz e Gomes (2018).

Ao realizar essas etapas dividiremos nossa pesquisa nos seguintes momentos: primeiro uma análise sobre o gradualismo que caracterizou a proposta do Estado Brasileiro para lidar com a abolição da escravidão. No segundo momento analisaremos como antecedente, a Lei de 1871 denominada de Lei do Ventre Livre. Os desdobramentos deste diploma legal foram fundamentais para a adoção de novas regras para tratar da escravatura no país. E por último mergulharemos nos debates e efeitos da Lei dos sexagenários.

\section{O GRADUALISMO}


O Estado brasileiro pós-independência não se pautou a partir da liberdade, mas sim da autoridade e dos interesses econômicos das elites do país. Longe de ser irrelevante, a colonialidade, evidenciada após o fim do colonialismo, se apresentou como elemento estruturante, estando arraigada na sociedade imperial. Manifestou-se em nossas instituições políticas e nas relações de dominação/opressão, permitindo que a forma de organização espacial e produtiva da colônia se perpetuasse capturando subjetividades e o imaginário social.

A escravidão contaminou as relações socioespaciais e foi apresentada como a única possibilidade existente para o "desenvolvimento" do país. As leis foram um instrumento poderoso na perpetuação da herança do colonialismo, contribuindo para a formação de uma verdadeira colonialidade do poder, do saber, e do ser, que marcaram a nossa formação social (CRUZ, 2017).

Roberto Schwartz (2012) denominou o período entre a independência e a prérepública, onde coexistiam as ideias liberais e escravistas, como uma verdadeira “comédia ideológica". Na visão do autor, a escravidão era abominável e incompatível com os princípios defendidos pelo liberalismo. Desta forma, o Brasil se caracterizou por ser um país independente, porém convivendo com o antagonismo de possuir uma economia agrária condicionada ao trabalho escravo e almejar estabelecer relações com mercado externo e seus princípios.

As ideias liberais circulavam amplamente entre a elite do país no pósindependência e o raciocínio burguês era inevitável pela nossa ligação com o mercado externo. Esse pensar, e todo conjunto ideológico produzido por ele, se chocaram com a escravidão institucionalizada, gerando uma incompatibilidade evidente. A escravidão, por sua própria existência, impossibilitava a liberdade e seus efeitos, sejam eles espaciais, econômicos, políticos ou sociais (SCHWARTZ, 2012).

Contudo, mesmo com todo esse contraste, o liberalismo brasileiro se caracterizou por permitir ao sistema se reproduzir em meio a contradição do trabalho escravo, o qual era entendido como a única forma possível de garantir o crescimento do país.

Essa tentativa de incorporar plenamente ideias europeias na formação da sociedade brasileira no pós-independência sem considerar as características próprias, fez com que o historiador Sergio Buarque de Holanda (1995) classificasse a sociedade brasileira do século XIX como desterrados em sua própria terra. Esse modelo só se tornou Revista da ABPN • v. 12, n. Ed. Especial - Caderno Temático: “Geografias Negras” • abril de 2020, p. 12-31 
possível graças aos interesses das elites brasileiras pela manutenção das características da colonialidade, se baseando em uma ilusão da continuidade dos laços com Portugal (SOUZA, 2017).

Nesse contexto a escravidão era a mais importante peça da engrenagem que movia a economia brasileira. Era a instituição que englobava todas as outras (SOUZA, 2017), permitindo que o modelo produtivo colonial pautado em relações raciais de exploração se tornasse a base para o desenvolvimento social do Brasil (NEGREIROS, 2010). A escravidão foi considerada por boa parte da elite do país como:

uma forma, rude embora, do direito; uma fase do progresso; um instrumento da civilização, como foi a conquista, o mancípio, a gleba. Na qualidade de instituição me parece tão respeitável como a colonização; porém muito superior quanto ao serviço que prestou ao desenvolvimento social. De feito, na história do progresso representa a escravidão o primeiro impulso do homem para a vida coletiva, o elo primitivo da comunhão entre os povos. $\mathrm{O}$ cativeiro foi o embrião da sociedade; embrião da família no direito civil; embrião do estado no direito público (CARVALHO, 2009, p.284).

O sistema político do Império foi organizado para conter os movimentos próabolição e proteger os interesses das elites escravocratas. Era sabido que a escravidão teria um fim, pois seria impossível manter esse sistema para sempre (MALHEIRO, 1866, p.41). Portanto, era necessário adiar ao máximo seu exaurimento absoluto.

A escravidão caduca, mas ainda não morreu; ainda se prendem a ela graves interesses de um povo. É quanto basta para merecer o respeito. No tênue sopro, que de todo não exalou do corpo humano moribundo, persiste a alma e, portanto, o direito. O mesmo acontece com a instituição: enquanto a lei não é cadáver, despojo inane de uma ideia morta, sepultá-la fora um grande atentado (CARVALHO, 2009, p.283).

A Lei foi o modo encontrado pelas elites para adiar ao máximo o fim do cativeiro no Brasil. A estratégia adotada para atender este fim foi criar regras para, supostamente, libertar os escravos paulatinamente, utilizando como argumento o véu da transição gradual. Nesse contexto, libertar os escravos aos poucos não visou atender interesses humanitários ou a qualquer tentativa de organização da nação, mas sim evitar que a Lei, a última esperança dos escravocratas, se tornasse "cadáver". O objetivo não era dar fim ao cativeiro, mas sim adiar ao máximo o sonho da liberdade. 
O gradualismo serviu como um freio para os movimentos abolicionistas. Sempre que a pressão para o fim definitivo aumentava, propunha-se uma nova norma e esta passava a ser o centro dos debates. Para os abolicionistas gerava-se a sensação de avançar, o que era interessante para a causa e, abolir a escravidão, ainda que lentamente, era melhor do que aceitar inerte à espera de um fim definitivo. Porém, já conscientes de que o cativeiro chegaria ao fim, este modelo também atendeu em grande medida os interesses escravocratas, os quais utilizavam o gradualismo para manobrar politicamente e continuar explorando a mão de obra escrava pelo maior tempo possível, garantindo assim maiores lucros em seus negócios (SILVA, 2018, p.148).

Ao longo desse estudo nos deparamos com um vasto material sobre o processo gradual de abolição de escravos no Brasil. São leis, decretos, discursos que evidenciam o momento turbulento vivenciado pelo país. Dentre todo material analisado escolhemos para como alvo para este estudo Lei $\mathrm{n}^{\circ} 3270$ de 28 de setembro de 1885, também chamada de Lei dos Sexagenários. Acreditamos que, dentro do contexto do Brasil Império, esta se caracterizou como a última grande tentativa de frear a abolição definitiva da escravidão que já ecoava pelo país.

\section{ANTECEDENTES: A LEI DE 1871}

Antes de adentrar propriamente no cenário turbulento dos anos de 1880, precisamos olhar para os antecedentes da década anterior, em especial o ano de 1871, quando é aprovada pelo congresso brasileiro em 28 de setembro a Lei Ventre Livre ${ }^{2}$.

Inserida dentro do contexto do gradualismo, a iniciativa para esta lei ganha força nos anos de 1860 quando, contrariando os interesses dos senhores de escravos, Dom Pedro II convida José Antônio Pimenta Bueno para elaborar um projeto legislativo que proporcionaria a emancipação dos cativos (MENDONÇA, 2018). A intenção era criar um programa de abolição de longo prazo que resolvesse a questão da escravidão legal no país (LAIDLER, 2013).

\footnotetext{
${ }^{2}$ Declara, entre outras medidas, livres os filhos de mulher escrava que nascerem a partir da data de publicação da Lei.
} abril de 2020, p. 12-31 
Essa iniciativa ganhou força após o fim da guerra do Paraguai em março de 1870 passando para o Congresso a missão de debater a questão. O processo de aprovação da Lei do Ventre Livre foi uma verdadeira, e aparentemente contraditória, batalha parlamentar. A questão de que a escravidão era indesejável e um problema para o país estava presente nos discursos dos deputados, porém se priorizava os "direitos existentes e os interesses essenciais da ordem pública: a lavoura, primeira indústria do país, e a segurança ou público sossego" (LAIDLER, 2013, p.171).

Após amplo debate, o projeto comandado pelo gabinete conservador do Visconde de Rio Branco, foi, após sucessivas emendas, aprovado na Câmara, com 61 votos favoráveis e 35 votos contrários ${ }^{3}$.

Em 28 de setembro de 1871 entrou em vigor a Lei ${ }^{\circ}$ 2040, denominada Lei do Ventre Livre, decretada pela Assembleia Geral e sancionada pela Princesa Imperial Regente Isabel. A lei ampliou, gradualmente, a emancipação de cativos, declarou livres os filhos de mulher escravas que nasceram a partir de sua publicação e estabeleceu regras sobre a criação e tratamento dos filhos menores e criou um fundo de liberdade de escravos.

Entre outras medidas, o elemento mais polêmico e que nomeou a Lei era o fim da doutrina legal do partus sequitur ventrem (o princípio de que o filho segue o ventre da mãe) (ARIZA, 2018). A partir de 28 de setembro de 1871 os ingênuos ${ }^{4}$ passam a ser livres no Brasil. Contudo, os menores libertos por esta Lei permaneceram sob o poder e autoridade dos senhores de escravos aos quais suas mães pertenciam. Estes tiveram a obrigação de criá-los e tratá-los até os oito anos de idade. A partir desta idade a Lei do ventre livre no Artigo $1^{\circ}$, parágrafo $1^{\circ}$ determina duas soluções possíveis. A primeira, o senhor deveriam entregar o menor ao governo que lhe daria destino e receberia a indenização de 600 mil réis; e a segunda o senhor poderia ficar com o menor e utilizar seus serviços gratuitamente até o mesmo completar a idade de 21 anos.

\footnotetext{
${ }^{3}$ De acordo com Laidler (2013), os votos contrários foram em sua maioria dos deputados ligados a grande lavoura escravista do Sul do país, ligada, sobretudo à agroexportação do café e os votos favoráveis foram em grande maioria dos representantes das províncias do Norte do país.

${ }^{4}$ Filhos livres de mulheres escravas após a Lei do Ventre Livre.
} abril de 2020, p. 12-31 
Esta medida, objeto de grande debate, foi inserida por emenda, servindo para atender aos desejos dos senhores que exigiam indenizações pelas supostas perdas oriundas dos efeitos da Lei.

A liberdade esculpida na Lei de 1871 se apresentou, como uma estratégia para adiar ainda mais o fim da escravidão. A regra onde os ingênuos deveriam permanecer sobre os cuidados dos senhores até os oito anos de idade, que ainda poderiam optar por manter seus serviços até os 21 anos ou receber uma indenização de 600 mil réis era na verdade uma ilusão para manter do cativeiro e reduzir a pressão para o fim do sistema escravista.

Não há dúvida da importância da Lei de 1871 para o país, principalmente pelos debates e pelo reconhecimento, ao menos teórico, de que todas as crianças que nasceram no país a partir de sua publicação seriam livres. Contudo, mesmo com os avanços alcançados, a Lei foi considerada por aqueles que defendiam a liberdade ampla no Império como:

imperfeita, incompleta, impolítica, injusta, e até absurda, como nos parece hoje, essa lei foi nada menos do que o bloqueio moral da escravidão. A sua única parte definitiva e final foi este princípio: "Ninguém mais nasce escravo." Tudo o mais, ou foi necessariamente transitório, como a entrega desses mesmos ingênuos ao cativeiro até aos vinte e um anos; ou in completo, como o sistema de resgate forçado; ou insignificante, como as classes de escravos libertados; ou absurdo, como o direito do senhor da escrava à indenização de uma apólice de $600 \$ 000$ pela criança de oito anos que não deixou morrer; ou injusto, como a separação do menor e da mãe, em caso de alienação desta. Isso quanto ao que se acha disposto na lei; quanto ao que foi esquecido o índice das omissões não teria fim. Apesar de tudo, porém, o simples princípio fundamental em que ela assenta basta para fazer dessa lei o primeiro ato de legislação humanitária da nossa História (NABUCO, 2003, p.78).

$\mathrm{Na}$ teoria o Brasil caminhava para a liberdade, entretanto, em termos práticos, a Lei do Ventre Livre serviu para dar mais segurança aos proprietários e legitimar a manutenção da escravidão por pelo menos mais uma geração (LAIDLER, 2013), acalmando com o véu do gradualismo, as reinvindicação dos abolicionistas e dos setores mais progressistas do país.

A mesma não representou o fim da escravidão de ingênuos no Brasil, pelo contrário, legitimou. Os casos de desrespeito à lei seguido de impunidade foram numerosos gerando sucessivas questões e criando um cenário de contínuas manifestações abril de 2020, p. 12-31 
e contestações à ordem escravista (MOURA, 2013). Esta conjuntura levou ao retorno do debate sobre a questão servil ao parlamento na primeira metade da década de 1880 (MENDONÇA, 2018).

\section{A LEI DOS SEXAGENÁRIOS DE 1885}

“Os que fizeram a lei de 28 de setembro de 1871 também pensavam que tinham resolvido o problema, mas está verificado quê não resolveram nada" (MOURA, 2013, p.240). Esta frase proferida pelo Deputado Zema na sessão da Câmara dos Deputados de 03 de julho de 1885 representa o sentimento dos abolicionistas e de grande parte da nação brasileira depois de percorrido mais de 10 anos da publicação da Lei do Ventre Livre.

Caso a Lei de 1871 tivesse sido aplicada poderia ter provocado transformações profundas na organização socioespacial do país. A expectativa do período era que a quantidade de negros livres modificaria completamente o espaço brasileiro, gerando transformações econômicas e políticas.

Graças aos poucos avanços práticos provocados pela referida Lei, a década de 1880 foi marcada pelo aumento da pressão pela abolição. Grupos abolicionistas nacionais e internacionais questionavam o congresso e se somavam ao clamor das ruas pela ampliação da liberdade.

A resposta das elites políticas do país a esse cenário seguiu a mesma linha adotada até então, o gradualismo. Tomados pelo temor de uma abolição imediata, ou que a demora em dar uma resposta ao ecoar abolicionista resultasse em uma revolta que comprometesse a ordem social, política e econômica do país, o parlamento voltou novamente seu olhar para a questão servil (MENDONÇA, 2018).

A abolição estaria feita! Todavia, ha treze annos, ahi está funccionando a lei de 28 de setembro; a morte dizimou cerca de meio milhão de opprimidos; e quão longe ainda não estamos da abolição annunciada, si o parlamento não se resolver a uma vigorosa reforma!

Emquanto a morte devora quinhentas mil criaturas humanas, a mola redemptora pomposamente magnificada sob o titulo de fundo de emancipação resgatou apenas 20.000, e a caridade individual cerca de 90.000 captivos. O resultado é ainda essa massa enorme de um milhão e cem mil escravos (BARBOSA, 1884, p.10). 
Sem resolver a questão a qual foi destinada, a Lei de 1871 contribuía mais para o caos, a miséria e a morte dos negros do que propriamente para sua liberdade. Quinhentos mil negros mortos em um período de pouco mais de 10 anos foi o resultado social da aplicação da Lei do Ventre Livre pelas elites brasileiras.

O problema era claro e os números mostravam que a proposta da Lei do Ventre Livre de ir, gradualmente, acabando com a escravidão não surtiu o efeito prometido. $\mathrm{O}$ processo de abolição estava lento demais e poderia adentrar até a primeira metade do século XX.

Pela lei de 28 de setembro de 1871, a escravidão tem por limite a vida do escravo nascido na véspera da lei. Mas essas águas mesmas não estão ainda estagnadas, por que a fonte do nascimento não foi cortada, e todos os anos as mulheres escravas dão milhares de escravos por vinte e um anos aos seus senhores. Por uma ficção de direito, eles nascem livres, mas, de fato, valem por lei aos oito anos de vida $600 \$$, cada um. A escrava nascida a 27 de setembro de 1871 pode ser mãe em 1911 de um desses ingênuos, que assim ficaria em cativeiro provisório até 1932. Essa é a lei, e o período de escravidão que ela ainda permite (NABUCO, 2018, p.171).

Seguindo este raciocínio a lei garantiria a manutenção da escravidão legal e suas repercussões socioespaciais até a primeira metade do século XX. Os efeitos econômicos que favoreceriam as elites estariam preservados, assim como a tragédia social sobre a população negra também.

Diante da questão, o parlamento não poderia deixar de se posicionar e apresentar propostas para uma solução do problema, caso contrário, um levante popular poderia comprometer a ordem social. Era notório o imenso medo de uma grande revolta de escravos no Brasil (CAMPELLO, 2018), sobretudo pelo grande número de contestações à escravidão que aconteceram no país durante o século XIX, principalmente em sua segunda metade (REIS, 2018).

O Brasil caminhava para o caos político e a principal razão era a questão da liberdade dos escravos. No Rio de Janeiro foi pulicado, em 1883, o Manifesto da Confederação Abolicionista, uma clara contestação aos interesses escravagistas. A província do Ceará foi mais além e decretou em 25 de março de 1884 o fím da escravidão na região (MARTINS, 2011), seguida pela província do Amazonas que em 10 de julho adotou a mesma postura. Pressionado por atitudes de contestação a ordem escravagista e abril de 2020, p. 12-31 
com número de revoltas e fugas crescendo, os debates no parlamento estavam cada vez mais acalorados.

Para acalmar a política interna e frear o crescente movimento abolicionista, o Imperador Dom Pedro II chamou o experiente político da Bahia Manuel Pinto de Sousa Dantas para suceder Lafayette Rodrigues Pereira e organizar um novo ministério (RAMOS, 2012).

Com a ascensão de Dantas ao cargo de presidente do Conselho de Ministros em 6 de julho de 1884, a ideia de uma nova legislação para atender aos anseios abolicionistas ficava cada vez mais próxima.

Os interesses do governo se concentraram em, principalmente, ampliar o fundo de emancipação e conceder a liberdade de escravos idosos sem a necessidade de indenização aos senhores (MENDONÇA, 1999).

Político experiente e liberal, Dantas consegue aglutinar apoio no parlamento e apresenta em julho de 1884 uma proposta ao Congresso, que visava, entre outras medidas, ampliar recursos para financiar o fundo de emancipação e libertar os escravos com mais de sessenta anos sem a necessidade do pagamento de indenização por parte do Império.

A recepção dessa proposta no parlamento causou grande debate e ampliou a cisão entre abolicionistas e escravagistas. O grupo de deputados ligados aos senhores de terra e de escravos exigiam a garantia do direito de propriedade e no mínimo uma reparação financeira pelos escravos que seriam libertos, retornando aos argumentos apresentados no debate para a aprovação da Lei do Ventre Livre, enquanto os liberais defendiam a liberdade sem condições.

Esse embate mergulhou o país em um verdadeiro caos político. A Lei do Ventre Livre, que no passado foi duramente criticada pelos escravagistas do país, agora era usada a favor. Os senhores de escravos defendiam manutenção dos termos da Lei de 1871 e, qualquer mudança era classificada como uma perturbação à ordem e um atentado contra o direto de propriedade (RAMOS, 2012). Obviamente, o interesse desse grupo na defesa da referida Lei estava em garantir o ritmo lento do gradualismo e a manutenção das indenizações que reafirmavam o direito de patrimonialista (SILVA, 2018).

Diante do cenário conturbado, Dantas pediu ao Imperador a dissolução do congresso, com intenção de que, através de novas eleições, fosse eleito um grupo maior de deputados liberais, facilitando assim a aprovação de projetos abolicionistas. O pedido Revista da ABPN • v. 12, n. Ed. Especial - Caderno Temático: "Geografias Negras” • abril de 2020, p. 12-31 
foi atendido e no fim de 1884 o parlamento foi dissolvido e uma nova eleição foi realizada (SABA, 2009).

Mesmo após a renovação do parlamento as disputas entre abolicionistas e escravagistas continuaram levando ao desgaste do Ministério. Incapaz de superar o boicote escravista as suas propostas, Dantas é destituído do cargo em 06 de maio de 1885, sendo substituído por José Antônio Saraiva, experiente político do partido Liberal e representante da Bahia (SABA, 2008).

Representante dos interesses escravistas, Saraiva encaminha ao parlamento uma proposta baseada na premissa de que era melhor fazer a reforma antes que outros a façam à revelia dos interesses conservadores da sociedade brasileira (SABA, 2009).

Apresentado em 12 de maio de 1885, o projeto Saraiva trazia alterações cruciais em relação ao apresentado por Dantas. Entre os principais pontos se destacam, a ampliação do prazo para a libertação de escravos de 60 para 65 anos, a adoção de indenização pela libertação dos escravos sexagenários, na forma de prestação de serviços por três anos, ou até completarem 65 anos de idade e a ampliação do fundo de emancipação, adotando diferentes taxas e seguindo o princípio de que a nação deveria arcar com o ônus da emancipação, anistiando assim os compradores (COSTA, 1999).

A mudança de postura foi comemorada pelos representantes escravagistas e representou uma contradição entre os membros do partido liberal que esperavam que o novo ministro fosse seguir os interesses abolicionistas. Em sessão na Câmara dos Deputados no dia 03 de julho de 1885, Joaquim Nabuco se posicionou questionando a postura adotada pelo presidente do conselho:

A esperança abolicionista, de que o Sr. presidente do conselho assigualasse a sua passagem pelo poder por um progresso qualquer sobre a sucessão política do seu antecessor, foi completamente iludida, e com profunda magua vimos, pelo contrario, S. Ex. apresentar-se-nos com um projecto que não tem outra causa por fim senão fazer do partido liberal, endurecido pelo cimento conservador, uma barreira á onda da liberdade e da justiça três vezes secular! (BRASIL, 1885, p.154).

Seguindo a mesma postura, o Deputado Leopoldo Bulhões criticou a postura conservadora e, indo mais além, defendeu a abolição imediata, apresentando argumentos favoráveis à mesma. Diferente do que apresentavam os deputados conservadores, na 
visão de Bulhões, o Brasil não entraria em crise caso a emancipação fosse imediata, pelo contrário a evitaria, e ainda resultaria em uma melhor organização econômica para o país.

Tanto quanto me podem autorizar os precedentes de outras nações, affirmarei que não provocará um desastre; ao contrario atenuar mais os perigos da crise do que o projecto actual... Diminuirá a exportação é certo; mas a importação se restringirá na mesma proporção. Assim nós, que importamos feijão, arroz da India sal farinha milho, etc. deixaremos de importar tudo isso, porque a pequena propriedade surgirá e ha de fornecer ao mercado esses generos de consumo geral. Sob o ponto de vista economico, o Brazil ainda vive no regime colonial: producção exclusiva e importação de tudo. Esta anomalia ainda resulta da escravidão e da grande lavoura (BRASIL, 1885, p.466).

A ótica apresentada pelo deputado romperia com os laços da colonialidade e colocaria o Brasil em um caminho de crescimento interno, com o desenvolvimento da produção local e o fim da escravidão. Segundo essa visão as transformações no espaço brasileiro seriam profundas, o mercado seria transformado e própria noção de país exportador seria alterada. Porém, mesmo fundamentada em experiências positivas de outros países, a proposta nunca chegou a ser aplicada.

Depois de intensos e acalorados debates, a proposta que se iniciou em 12 de maio de 1885, e que garantiu os interesses dos setores interessados na manutenção da escravidão no país, foi aprovada na Câmara dos Deputados em 13 de agosto de 1885 (RAMOS, 2012).

Seguindo para o Senado os debates continuaram, contudo sem Saraiva, que se retirou do cargo ainda em agosto do mesmo ano devido ao desgaste político que sofreu dentro do próprio partido. Para o seu lugar, Dom Pedro II nomeou o deputado do partido Conservador João Maurício Wanderley, o Barão de Cotegipe (SABA, 2008).

A chegada de um membro do partido Conservador ao poder foi considerada decisiva para concluir a tramitação do projeto Saraiva. Assim, no dia 28 de setembro de 1885, foi confirmada no Senado a Lei Saraiva-Cotegipe, denominada de Lei dos Sexagenários.

Aprovada com a intenção de estabelecer uma nova regulação para garantir, paulatinamente, a extinção do elemento servil, a Lei 3270 de 1885, inicialmente, determinou uma nova matrícula dos escravos. Dessa vez, diferente do determinado pela 
Lei do Ventre Livre, exigiu a nacionalidade e o valor de cada escravo, sendo os mesmos tabelados na própria Lei.

A criação dessa tabela visou, principalmente, uniformizar o valor a ser pago e evitar maiores prejuízos com a queda do preço do escravo devido a todo contexto favorável à emancipação (MENDONÇA, 2008).

Tabela 1: Valor do escravo em conto de Réis de acordo com a Lei 3.270 de 1885.

\section{Valor do escravo em conto de Réis de acordo com a Lei 3.270 de 1885}

Escravos menores de 30 anos.

Entre 30 e 40 anos.

Entre 41 e 50 anos.

Entre 51 e 55 anos.

Entre 56 e 60 anos.
900 contos de Réis

800 contos de Réis

600 contos de Réis

400 contos de Réis

200 contos de Réis

No caso de indivíduos do sexo feminino, o valor era abatido em $25 \%$ sobre os preços acima estabelecidos.

Fonte: Artigo $3^{\circ}$, Lei no 9.517 de 14 de novembro de 1885 [Lei dos Sexagenários].

A lei também definiu os critérios para a alforria pelo fundo de emancipação, determinando sua composição e as regras de seu funcionamento (Coleção das leis do Império do Brasil, 1885).

No artigo $3^{\circ}$ parágrafo 10 , foi esculpida a regra que nomeia a Lei. Os escravos com idade superior a sessenta anos de idade estariam livres, todavia essa liberdade não seria plena, pelo contrário, seria precarizada, possuindo a condição, a título de indenização, do comprimento de mais três anos de trabalho para o seu ex-senhor.

É fundamental ressaltar que a expectativa de vida de um cidadão livre no período imperial não era superior a 65 anos de idade. No caso dos escravos, devido ao contexto em que estavam inseridos, não era superior a 30 anos de idade, ou seja, eram raros os casos de escravos, que após anos de trabalho forçado, má alimentação e insalubridade chegassem aos 60 anos (KARASCH, 2000).

Essa análise mostra toda a perversidade do sistema escravista, ou seja, mesmo que o escravo chegasse a ser sexagenário, ainda assim seria obrigado a trabalhar por mais três anos para "pagar" uma indenização ao seu ex-senhor, caracterizando a exploração

Revista da ABPN • v. 12, n. Ed. Especial - Caderno Temático: "Geografias Negras”" abril de 2020, p. 12-31 
máxima da força de trabalho até o seu exaurimento completo, embora o cativo não possuísse condições plenas de trabalho ainda era possível se obter lucro com sua exploração.

Após ser liberto, mesmo após cumprir o tempo obrigatório de serviço, o escravo sexagenário não estaria totalmente livre. Para impedir que senhores abandonassem seus ex-escravos idosos e incapazes foi determinado que os que fossem contemplados pela Lei continuassem sob a guarda do seu antigo senhor, visto que este possuía a obrigação de cuidado, podendo usufruir dos serviços do ex-cativo na medida de sua força.

Os ex-escravos poderiam buscar outro meio de sustento fora do alcance do seu antigo senhor, porém, para isso, dependiam da autorização do juizado de órfão, que era o órgão competente para analisar a capacidade dos mesmos para exercer a função escolhida.

No caso de alcançar a emancipação e se ver livre definitivamente, seja pelo fundo de emancipação ou por idade, o ex-escravo ainda não alcançava a liberdade plena. A Lei dos Sexagenários proibia a livre circulação de ex-cativos pelo país, devendo os mesmos ficar, obrigatoriamente, pelo período de 5 anos, confinados ao município onde foram alforriados.

Em caso de ausência, os libertos eram considerados vagabundos e deveriam ser apreendidos pela polícia para ser empregados em trabalhos públicos ou em colônias agrícolas em uma estratégia clara de marginalização e terror racial com objetivo de manter a estrutura racista de inferioridade negra (NEGREIROS, 2010).

Com essas regras, a Lei dos Sexagenários se caracterizou por ser um complicadíssimo diploma legal, com claras violações à liberdade e a inserção do negro na sociedade e no espaço brasileiro.

Ser livre possui como uma de suas premissas a capacidade mover-se segundo suas próprias escolhas. De acordo com Mattos (2013) a mobilidade espacial foi característica marcante durante os períodos colonial e imperial, fruto da ampliação da área ocupada pelo país.

Segundo a autora a migração era uma opção permanente nas estratégias de sobrevivência de um país em expansão, famílias formadas por ex-escravos buscavam a mobilidade como estratégia para alcançar o sustento de seus membros. Acreditavam que vivendo distante da comunidade onde foram escravizadas reduziriam o preconceito e teriam novas possibilidades econômicas e sociais.

Revista da ABPN • v. 12, n. Ed. Especial - Caderno Temático: “Geografias Negras”" • abril de 2020, p. 12-31 
Ao estabelecer, a título de indenização o período de mais três anos de trabalho além dos sessenta anos e limitar a circulação de ex-escravos por mais cinco anos, a Lei de 1885 se caracterizou como uma política que visava limitar esta estratégia, deixando claro o interesse das elites em manter a precarização socioespacial do negro no Brasil, uma vez que já estando em condição de vulnerabilidade pela idade avançada, o mesmo não poderia romper com os laços sociais e espaciais que o escravizaram.

Assim, a precarização socioespacial deve ser entendida aqui, como a tentativa de manutenção da estrutura racista e de inferioridade do negro, através de políticas que dificultaram sua capacidade de conviver na sociedade como cidadão livre, somada a limitações de mobilidade pelo espaço brasileiro.

Neste caso específico, a Lei não foi aplicada para promover a emancipação plena, mas sim para acalmar o movimento abolicionista e retardar o máximo possível o fim da escravidão no país, sendo adotada tardia e inadequadamente à realidade brasileira (CAMPELLO, 1986).

A intenção de evitar o fim definitivo da escravidão não obteve grande êxito após a Lei de 1885, pelo contrário, gerou mais insatisfação popular e proporcionou um cenário favorável para a abolição definitiva. Nesse contexto, é que menos de dois anos depois de sua promulgação, as autoridades brasileiras não conseguiram mais conter a massa de cativos que abandonavam as propriedades agrícolas e partiam em direção às províncias onde a abolição já havia ocorrido, em busca da sua liberdade de fato (CAMPELLO, 2018).

Com o sistema ruindo e diante do clima de desobediência civil, a solução para o problema foi mais uma vez recorrer ao legislativo que, sem alternativa para frear o fim da escravidão, que já se materializava na prática, aprovou, em uma tramitação extremamente rápida, em apenas 5 dias, o fim definitivo do cativeiro legal no Império do Brasil com a promulgação em 13 de maio de 1888 da Lei Áurea (CAMPELLO, 2018).

\section{CONCLUSÃO}

O Estado Brasileiro se organizou a partir da colonialidade, buscando manter as estruturas socioeconômicas pautadas na escravidão e na precarização socioespacial do 
negro, garantindo assim a manutenção dos privilégios da elite política e econômica que participava da administração colonial.

Entre o pós-independência e o pré-república, o Brasil vivenciou um cenário aparentemente contraditório onde cativeiro convivia em harmonia com ideias liberais garantindo maiores lucros para os senhores de terra e de escravos, e uma desigualdade estruturante para a maioria da população, em especial, os negros escravizados e/ou subalternizados.

Este modelo foi alvo de questionamentos internos e externos e, com o avançar do século XIX, foi se reestruturando, principalmente no que tange a escravidão legal, cada vez mais protestada. Uma das estratégias principais para manter a proteção ao cativeiro foi a confecção de medidas legislativas que aparentemente libertassem escravos, mas que ao mesmo tempo garantissem a escravidão pelo maior tempo possível.

O gradualismo foi o maior exemplo dessa estratégia uma vez acalmava os ânimos abolicionistas, entretanto garantia a estrutura perversa da escravidão legal por mais tempo. A primeira grande medida dessa linha foi a Lei do Ventre Livre de 1871, que visava garantir a liberdade dos negros nascidos após sua entrada em vigor. Porém, garantia aos mesmos a condição de cativo por 21 anos, a depender da vontade do senhor. O resultado prático desta lei é que ela não atendeu aos interesses abolicionistas e manteve o terror e a estrutura socioespacial do Brasil intacta, com a economia agroexportadora e a sociedade desigual e escravocrata.

Sendo considerada imperfeita, incompleta, e até mesmo, absurda, a Lei de 1871 foi alvo de intensos debates na sociedade e no parlamento. As discussões cada vez mais intensas levaram a uma nova medida legislativa, a qual vinha com a promessa de ampliar a liberdade e dar prosseguimento ao gradualismo.

Durante os debates que questionavam os resultados da Lei do Ventre Livre surgiram propostas como a do Deputado Leopoldo Bulhões. Pautado em experiências vivenciadas por outros países, este parlamentar argumentava que o fim da escravidão levaria o Brasil a outro caminho de desenvolvimento, com a diminuição da importação de gêneros alimentícios essenciais e o crescimento da pequena propriedade para atender o mercado interno. Propostas como esta surgiram, mas como não atendiam ao interesse da elite, nunca foram levadas a diante. Independente dos seus desdobramentos, se efetivadas transformariam a realidade socioespacial do país.

Revista da ABPN • v. 12, n. Ed. Especial - Caderno Temático: “Geografias Negras”" • abril de 2020, p. 12-31 
A proposta que passou pelo congresso foi muito mais modesta em termos de transformação. Foi aprovada em 28 de setembro de 1885 a Lei dos Sexagenários. Esta foi apresentada com uma medida que libertaria os escravos maiores de sessenta anos, contudo tabelou o preço dos escravos para evitar prejuízos aos senhores com a desvalorização do "produto" e precarizou a liberdade dos cativos idosos.

De início a faixa etária determinada pela Lei como a mínima para obtenção da liberdade, atenderia a uma parcela ínfima levando em consideração a expectativa de vida de um escravo na época, além do fato desta liberdade ser condicionada.

Só estariam livres os escravos que não fossem considerados incapazes, os quais deveriam permanecer sobre os cuidados do senhor. Esta medida visava evitar uma estratégia comum e extremante cruel, uma vez que os escravos incapazes, que na grande maioria dos casos atingiam esse estágio devido aos trabalhos forçados, eram abandonados por seus senhores nas cidades ou regiões distantes dos seus locais de origem, aumentando ainda mais sua miserabilidade.

Além desta medida, a Lei também manteve a precarização socioespacial para os negros ao impor restrições temporais, que ampliavam para além dos sessenta anos o tempo de trabalho, e espaciais que impediam o negro de circular livremente pelo país, se caracterizando como uma estratégia de inadequação do negro como pessoa ao espaço brasileiro. Este não poderia circular livremente pelo território do país, devendo ficar restrito ao controle do seu antigo senhor.

As restrições socioespaciais desta Lei foram incompatíveis com os anseios de grande parte da população e, com o aumento da desobediência civil e receio de uma revolta, não restou outra alternativa que não a abolição completa que se efetivou através da Lei Áurea em maio de 1888.

\section{REFERÊNCIAS BIBLIOGRÁFICAS}

ARIZA, Marília. Crianças/Ventre Livre. In: SCHWARCZ, Lilia Moritz e GOMES, Flávio dos Santos. (orgs.) Dicionário da escravidão e liberdade: 50 textos críticos. São Paulo: Companhia das letras, 2018.

BARBOSA, Ruy. 1849-1923 Emancipação dos escravos: parecer formulado pelo deputado Ruy Barbosa como relator das Commissões Reunidas de Orçamento e Justiça Civil. Rio de Janeiro: Typ. Nacional, 1884. 
BRASIL. Anais da Câmara dos deputados do Império. 03 de julho de 1885. Brasil. Congresso Nacional. Câmara dos Deputados. Rio de Janeiro: Imprensa Nacional, 1885. Disponível em: http://www2.camara.leg.br/atividade-legislativa/plenario/discursos/escrevendohistoria/125anos-da-lei-aurea/euzebio-queiroz. Acesso em: 25 de outubro de 2018.

BRASIL. Lei $n^{\circ} 9.517$ de 14 de novembro de 1885 [Lei dos Sexagenários]. Coleção das leis do Império do Brasil, Rio de Janeiro, p. 738, v. 1, 1886. Disponível em: https://www2.camara.leg.br/legin/fed/decret/1824-1899/decreto-9517-14-novembro-1885543970-publicacaooriginal-54764-pe.html. Acesso em: 25 de outubro de 2018.

CAMPELLO, André Barreto. Manual Jurídico da Escravidão. São Paulo: Paco, 2018.

CARVAlHO. José Murilo de. (org.) Cartas de Erasmo / José de Alencar. Coleção Afrânio Peixoto; v. 90. Rio de Janeiro: ABL, 2009.

Coleção de Leis do Império do Brasil - 31/12/1885 - Vol. 1. Disponível em: http://legis.senado.leg.br/legislacao/DetalhaSigen.action?id=545046. Acesso em: 25 de outubro de 2018.

COSTA, Emília Viotti da. Da Monarquia à República. Momentos Decisivos. São Paulo: Unesp, 1999.

CRUZ, Valter do Carmo. Geografia e pensamento descolonial: notas sobre um diálogo necessário para a renovação do pensamento crítico. In: CRUZ, V. C.; OLIVEIRA, D. A. Geografia e giro descolonial: experiências, ideias e horizontes de renovação do pensamento crítico. Rio de Janeiro: Letra Capital, 2017.

HOLANDA, Sérgio Buarque. Raizes do Brasil. $26^{\mathrm{a}}$ ed. São Paulo: Companhia das Letras, 1995. KARASCH, Mary. A Vida dos Escravos no Rio de Janeiro (1808-1850). São Paulo: Companhia das Letras, 2000.

LAIDLER, Christiane Vieira. A Lei do Ventre Livre: interesses e disputas em torno do projeto de 'abolição gradual'. Escritos (Fundação Casa de Rui Barbosa), v. 5, p. 169-205, 2013.

MALHEIRO, Agostinho Marques Perdigão. A escravidão no Brasil: ensaio histórico, jurídico, social. Parte I. Rio de Janeiro: Typographia Nacional, 1866.

MATTOS, Hebe. Das cores do silêncio: os significados da liberdade no sudeste escravista (Brasil, século XIX). Campinas, SP: Editora da Unicamp, 2013.

MARTINS, Paulo Henrique de Souza. Abolição e Pós-Abolição no Ceará: sobre silêncios e memórias de uma história laureada (1881-1934). In: Simpósio Nacional de História, 26., 2011, São Paulo. Anais... São Paulo: ANPUH: 50 anos, 2011.

MENDONÇA, Joseli Maria Nunes. Entre a mão e os anéis: a Lei dos Sexagenários e os caminhos da abolição no Brasil. Campinas, SP: Editora da Unicamp; Centro de Pesquisa em História Social da Cultura, 1999.

. Legislação Emancipacionista, 1871 e 1885. In: SCHWARCZ, Lilia Moritz e GOMES, Flávio dos Santos. (orgs.) Dicionário da escravidão e liberdade: 50 textos críticos. São Paulo: Companhia das letras, 2018.

NABUCO, Joaquim. O abolicionismo. Brasília: Senado Federal, Conselho Editorial, 2003.

Revista da ABPN • v. 12, n. Ed. Especial - Caderno Temático: "Geografias Negras"• abril de 2020, p. 12-31 
NEGREIROS. Dalila Fernandes de. Raça e desterritorialização: uma proposta de análise geográfica da diáspora africana. Revista $A B P N$, v. 1, n. 2., jul.-out. de 2010, p. 67-83.

RAMOS, Ana Flávia Cernic. História e Crônica: a Lei dos Sexagenários e as Balas de Estalo de Machado de Assis (1884-1885). Revista História Social, v. 1, 2012, p. 61-82.

REIS. Isabel Cristina Ferreira dos. Breves reflexões acerca da historiografia sobre a família negra na sociedade escravista brasileira oitocentista. Revista $A B P N$, v. 1, n. 2., jul. -out. de 2010, p. 113132.

REIS. João José. Revoltas Escravas. In: SCHWARCZ, Lilia Moritz e GOMES, Flávio dos Santos. (orgs.) Dicionário da escravidão E liberdade: 50 textos críticos. São Paulo: Companhia das letras, 2018.

SABA, Roberto. A Lei dos Sexagenários no Debate Parlamentar (1884-1885). In: Encontro Regional de História, 19., 2008, São Paulo. Anais... São Paulo: ANPUH, 2008.

- A Lei dos Sexagenários e a derrota política dos Abolicionistas no BrasilImpério. História Social (UNICAMP), v. 14/15, p. 21-33, 2009.

SCHWARZ, Roberto. Ao Vencedor as Batatas: Forma literária e processo social nos inícios do romance brasileiro. $6^{\text {a }}$ ed. São Paulo: Editora 34, coedição ed. Duas Cidades, 2012.

. Ao Vencedor as Batatas: Forma literária e processo social nos inícios do romance brasileiro. $6^{\text {a }}$ ed. São Paulo: Editora 34, coedição ed. Duas Cidades, 2012.

SILVA, Juremir Machado da. Raizes do conservadorismo brasileiro: a abolição na impressa e no imaginário social. $3^{\mathrm{a}}$ ed. Rio de Janeiro: Civilização Brasileira, 2018.

SOJA, Edward. Geografias pós-modernas: a reafirmação do espaço na teoria social crítica. Rio de Janeiro: Zahar, 1993.

SOUZA, Jessé. A Elite do Atraso: Da Escravidão à Lava Jato. São Paulo: Editora Leya, 2017.

Recebido 20/02/2020

Aprovado em 30/03/2020

Revista da ABPN • v. 12, n. Ed. Especial - Caderno Temático: "Geografias Negras"• abril de 2020, p. 12-31 